\title{
Development and Trends of Depreciation Policy in Slovak Republic
}

\author{
Adela Poliakova ${ }^{1, *}$ \\ ${ }^{1}$ University of Zilina, Faculty of Operation and Economics of Transport and Communication, \\ Department of Economics, Univerzitna 1, 01026 Zilina, Slovakia.
}

\begin{abstract}
.
Research background: Depreciation as such represents a significant component of business costs. It is known that in the current legislation in the Slovak Republic there was no depreciation in the depreciation group with a depreciation period of 2 years. As part of increasing the motivation of the business sector to procure low-emission or emission-free transport, an amendment to the Income Tax Act was adopted with effect from the beginning of 2020, which introduces a new depreciation group 0 and favours the depreciation of electric vehicles. The newly introduced depreciation group zero has a strong ecological subtext.

Purpose of the article: The article deals with the development of depreciation policy in the conditions of the Slovak Republic, compares the current situation with the situation in the Czech Republic and on the example of practical calculations of depreciation. The aim of the paper is to compare current trends in depreciation policies in the context of supporting the greening of transport.

Methods: We used methods of analysis and comparing.

Findings \& Value added: Based on an extensive analysis, the article maps the most significant changes in the depreciation policy. Within the historical development of today's tax depreciation, several trends are manifesting that are favourable for the business environment. The depreciation policy in the Czech Republic has not undergone such extensive changes as in Slovakia, where the most recent change in the recent period is the introduction of a depreciation group with a depreciation period of 2 years.
\end{abstract}

Keywords: depreciation policy; depreciation; depreciation group; depreciation period

JEL Classification: $M 41 ; M 48 ; K 34$

\footnotetext{
* Corresponding author: adela.poliakova@,fpedas.uniza.sk
} 


\section{Introduction}

Tax expenditures that can be claimed only to the extent and under the conditions stipulated by the Income Tax Act include depreciation of tangible and intangible assets (Section 19 (3) (a) of the Income Tax Act). The acquisition price of tangible and intangible assets is not allowed by the Income Tax Act to be included in tax expenses at the time of purchase (acquisition) in full, but only gradually through depreciation, in accordance with Sections 22 to 29 of the Income Tax Act $[1,2]$.

Depreciation defines [3] as the gradual inclusion of depreciation of tangible assets and intangible assets that are accounted for (in single or double-entry bookkeeping) or recorded (in tax records) and are used to secure taxable income, in tax expenses, Depreciation, as a cost item, they are an expression of the long-term wear and tear and obsolescence of tangible and intangible assets during a given accounting period.

According to [4], it is the logical effort of every taxpayer to keep the calculated income tax in the ola tax return as low as possible. One of the possibilities of tax optimization for personal and corporate income tax is a correctly chosen tax depreciation policy, which includes both the choice of depreciation method, but also the use of the possibility of interruption of depreciation.

We get used to look at the issue of depreciation from an accounting and tax point of view. From an accounting point of view, depreciation should reflect the real wear and tear of the assets used, so the method of determining them can be chosen by the entity itself, taking into account the intensity of use or obsolescence of assets. [5] states that from the tax point of view, depreciation is seen as an expense to achieve, secure and maintain income, when their calculation is already subject to the relevant regulations. Therefore, the entity must respect the limits set by the state, as the entity will significantly reduce its tax liability through depreciation.

In the Balance Sheet of companies, fixed assets are considered the goods destinated to the operations of the company. In this context, depreciation corresponds to a decrease of property value resulting from the usage of the goods, the action of the nature of obsolescence [6].

At present, an entity can choose between two types of tax depreciation: straight-line and accelerated. Accounting depreciation does not have a precisely defined method of calculating depreciation. Therefore, the entity chooses depreciation according to its own depreciation policy, while it is permissible to consider the actual use and obsolescence of assets. We always depreciate fixed assets up to the amount of the entry price (with respect to possible technical improvements). According [7] the choice of depreciation method is strictly regulated by legislation - the method of depreciation, the amortization period and the changes of depreciation plans.

Comparing Slovak legislation - Act on Accounting and the Measures of accounting procedures, the major differences are in the measurement of assets, in the recognition of the assets, in the method of assets depreciation, an impairment of assets [8].

With problem of depreciation deal more foreign studies.

According [9] since the purpose of optimization is to maximize the amount of depreciation in the initial periods of equipment operation, which would make it possible for the enterprise to maximize the amount of funds for the modernization of fixed assets with a subsequent increase in the amount paid for income and property taxes, the following limitations should be taken into account:

- funds received through the minimization of taxes on income and property are allocated for the purchase of additional equipment;

- depreciation accruing on newly purchased fixed assets should be made in the manner that minimizes the amount of depreciation in the initial operation periods. 
[10] examined mainly conflicting recommendations from the practitioner literature about the proper adjustment for deferred taxes and claimed that incentive alignment for owner and manager can be achieved by correct depreciation schedule of property.

[11] has published a study which has successfully identified and analysed the relevant sustainable design factors that most likely contributes to the commercial property depreciation and obsolescence.

A study from Russia by [12] claims, that the accounting unit of fixed assets in the Russian legislation is defined as an inventory object. In IFRS, only a depreciation unit is determined because of useful life. In their opinion, the difference should remain, since one of the requirements of accounting is the requirement of "substance over form".

For [13] the fixed asset management is not an easy case. Management on the firm must "confront" several difficult issues when acquiring an asset, such as the classification, the valuation method and measurement, the monitoring, the depreciation of its value and the effects of each decision, relating to fixed assets, in the income statement and shareholders' equity.

In his study Diewert [14] deals with commercial property depreciation. According to [14] traditional depreciation models for structures (such as the one hoss shay, geometric or straight-line models) are unlikely to provide adequate descriptions of economic reality for the commercial property sector.

An ecologic character also has a [15] study, where authors have found out that while the building age plays an important role to the rental depreciation, other factors such as building categories and building classifications in regards to green building certification may also influence the depreciation rate of office buildings.

\section{Development of Depreciation Policy in Slovak Republic}

Until the division of the Czechoslovak Socialist Republic, the Act no. 286/1992 Coll. was compulsory for both - Slovak and Czech Republic. This act the independent Slovak Republic took over in full until the year 2000, when the new Act no. 366/1999 Coll. on income taxes was accepted.

In the following text, we will pay more attention to the development of depreciation in the Slovak Republic in the last 20 years.

Starting on 1 January 2000, the thresholds for the compulsory inclusion of assets in depreciation were set as follows:

a) tangible assets with an entry price of SKK 20,000 ,

b) intangible assets with an entry price from SKK 40,000.

During this period, the term "investment" ceases to be used to designate such classified assets. A significant, and beneficial for taxpayers, change can be considered a new possibility to apply the suspension of depreciation depending on the choice of the accounting unit, which until then the accounting entity could do only without the possibility of extending depreciation. From 1 January 2020, an entity may suspend depreciation for one or more accounting periods and extend the depreciation period by the period of interruption. Like all tax laws, this one has been amended several times. From the point of view of depreciation, the amendment to Act no. 561/2001 Coll., Which entered into force on 1 January 2003 and which also brought a change in the limits for the mandatory inclusion of the entry price in costs in the form of depreciation as follows:

a) tangible assets with an entry price of SKK 30,000 ,

b) intangible assets with an entry price from SKK 50,000.

The said law was valid until the adoption of Act no. 595/2003 Coll. on income tax, which entered into force on 1 January 2004. In addition to the change in title, the new law introduced other changes. The legislation in force until then contained a limit on the 
maximum amount of the entry price from which the means of transport were depreciated. The new regulation lifted this restriction. As part of depreciation, the law regrouped the inclusion of individual types of tangible assets, while introducing the use of only four depreciation groups.

Table 1. Development of changes in depreciation period.

\begin{tabular}{|c|c|c|c|c|c|c|}
\hline \multirow[b]{2}{*}{$\begin{array}{l}\text { Deprecia- } \\
\text { tion group }\end{array}$} & \multicolumn{6}{|c|}{ Depreciation period (in years) } \\
\hline & $\begin{array}{c}\text { Act no. } \\
286 / 1992 \\
\text { Coll. (from } \\
1^{\text {st } J a n u a r y ~} \\
1993 \text { till } \\
31^{\text {st }} \\
\text { December } \\
1999 \text { ) }\end{array}$ & $\begin{array}{c}\text { Act no. } \\
366 / 1999 \\
\text { Coll. } \\
{\text { (from } 1^{\text {st }}} \\
\text { January } \\
2000 \text { till } \\
31^{\text {st }} \\
\text { December } \\
2002 \text { ) } \\
\end{array}$ & $\begin{array}{l}\text { Act no. } \\
366 / 1999 \\
\text { Coll. } \\
{\text { (from } 1^{\text {st }}}^{\text {January }} \\
2003 \text { till } \\
31^{\text {st }} \\
\text { Decembe } \\
\text { r 2003) }\end{array}$ & $\begin{array}{l}\text { Act no. } \\
595 / 2003 \\
\text { Coll. } \\
{\text { (from } 1^{\text {st }}}^{\text {January }} \\
2004 \text { till } \\
31^{\text {st }} \\
\text { Decembe } \\
\text { r 2014) }\end{array}$ & $\begin{array}{l}\text { Act no. } \\
595 / 2003 \\
\text { Coll. } \\
{\text { (from } 1^{\text {st }}} \\
\text { January } \\
2015 \text { till } \\
31^{\text {st }} \\
\text { Decembe } \\
\text { r 2019) }\end{array}$ & $\begin{array}{c}\text { Act no. } \\
595 / 2003 \\
\text { Coll. } \\
{\text { (from } 1^{\text {st }}} \\
\text { January } \\
2020 \text { ) }\end{array}$ \\
\hline 0 & - & - & - & - & - & 2 \\
\hline 1 & 4 & 4 & 4 & 4 & 4 & 4 \\
\hline 2 & 8 & 8 & 6 & 6 & 6 & 6 \\
\hline 3 & 15 & 15 & 12 & 12 & 8 & 8 \\
\hline 4 & 30 & 30 & 20 & 20 & 12 & 12 \\
\hline 5 & 50 & 40 & 30 & - & 20 & 20 \\
\hline 6 & - & - & - & - & 40 & 40 \\
\hline
\end{tabular}

Source: Cited acts.

An important change can be considered the fact that since 2004, in certain cases, in addition to the owner, the real user of the property can also depreciate. This provision was a step-in resolving disputes in the case of the use of assets acquired in the form of a finance lease. After many amendments, the law still applies today. In connection with the changeover to the euro and the relevant provisions of the adopted Act no. 465/2008 Coll. (Act amending the laws within the competence of the Ministry of Finance of the Slovak Republic in connection with the introduction of the euro in the Slovak Republic) the limits for the mandatory classification of assets with effect from 1 January 2009 were defined as follows:

a) tangible assets with an entry price from EUR 996,

b) intangible assets with an entry price of EUR 1,660 or more.

These limits were created by conversion at the conversion rate of 30.126 SK / EUR, but these limits have been significantly increased by two months with effect from 1 March 2009, as follows:

a) tangible assets with an entry price from EUR 1,700, 
b) intangible assets with an entry price of EUR 2,400 or more.

These limits are valid still today.

The use of four depreciation groups lasted quite a long time - ten years. After ten years, tangible assets are amended by Act no. 333/2014 Coll. regrouped into several depreciation groups. The sixth group has survived to this day, but to the six depreciation groups has been added since the beginning of this year the so-called zero group, as a reaction to the effort to favour more environmentally friendly modes of transport, when there is an advantage for electric cars.

Table 1 provides an overview of how the depreciation period of property has changed.

\subsection{Depreciation methods}

Depreciation policy in the Slovak Republic is currently regulated by Act no. 595/2003 Coll. on income tax, as amended. The issue of depreciation can be found in $\S 22-\S 29$ of this Act.

At the beginning of depreciation, the entity chooses the depreciation method: straightline or accelerated. In the case of straight-line depreciation, the annual depreciation is determined as the ratio of the input price of tangible assets to the depreciation period set for the relevant depreciation group. Accelerated depreciation has changed considerably in the individual stages of development. Until the introduction of six depreciation groups, it was possible to depreciate tangible assets included in any depreciation group in an accelerated manner; from 1 January 2015, it is possible to depreciate acceleratedly only assets in groups 2 and 3. At present, depreciation groups 2 and 3 assign the following coefficients for accelerated depreciation (Table 2):

Table 2. Coefficients for accelerated depreciation.

\begin{tabular}{|c|c|c|c|}
\hline $\begin{array}{c}\text { Depreciatio } \\
\text { n group }\end{array}$ & $\begin{array}{c}\text { First year } \\
\text { of } \\
\text { depreciatio } \\
\text { n }\end{array}$ & $\begin{array}{c}\text { Following } \\
\text { years of } \\
\text { depreciatio } \\
\text { n }\end{array}$ & $\begin{array}{c}\text { For increased } \\
\text { residual } \\
\text { value }\end{array}$ \\
\hline 2 & 6 & 7 & 6 \\
\hline 3 & 8 & 9 & 8 \\
\hline
\end{tabular}

Source: Actual Act no. 595/2003 Coll. on income tax

In the case of accelerated depreciation of tangible assets, depreciation of tangible assets is determined as follows:

a) in the first year of depreciation of tangible assets, only a proportion of the annual depreciation determined as a share of the input price and the assigned coefficient for accelerated depreciation of tangible assets valid in the first year of depreciation depending on the number of months

b) in subsequent years of depreciation of tangible assets, as a proportion of twice their residual value and the difference between the assigned accelerated depreciation coefficient applicable in subsequent years of depreciation and the number of years during which they have already been depreciated; for the purpose of calculating annual depreciation only

1. in the second year of depreciation, the residual value of tangible assets is determined as the difference between the input price and the share of its input price and the assigned accelerated depreciation coefficient valid in the first depreciation year not reduced by a proportion of annual depreciation not applied to tax expenses in the first depreciation year, 
2. in subsequent depreciation years, the residual value determined in accordance with point 1 shall be reduced by the tax depreciation on these assets included in tax expenditure, starting from the second year of depreciation.

As the accelerated depreciation adjustment has undergone extensive development, we will not devote more space to it for the purposes of this article.

The entity chooses the depreciation method at the beginning of depreciation. Although the chosen method of depreciation does not affect the length of depreciation, it significantly affects the amount of costs and thus the economic result. As the different course of depreciation affects the amount of the income tax base, it also affects the amount of the tax itself.

\subsection{Last significant changes in depreciation in Slovak Republic}

The last change in the current law, which entered into force on 1 January 2020, introduced the possibility of depreciating electric cars. This change was introduced in connection with the support of ecological transport, with the support of electromobility. A new depreciation group 0 has been introduced, with a depreciation period of 2 years. Depreciation group 0 includes passenger cars which have the abbreviation in the type of fuel / energy source item in the certificate of registration:

- $\quad$ BEV (Battery Electric Vehicle) - refers to an exclusively electric vehicle. Such a vehicle is powered by an electric motor and its source of energy is a battery, the capacity of which determines its range. BEV has no internal combustion engine or any other option than to generate electricity,

- $\quad$ PHEV (Plug-in Hybrid Electric Vehicle) - this is a hybrid electric vehicle, whose battery can be recharged by connecting to an external power source, but also using a built-in motor and generator. The preferred depreciation method can be applied to a plug-in hybrid electric vehicle that has any combination with another type of fuel or energy source. [3]

For the business environment in Slovakia, the possibility of writing off an electric car for two years is a positive phenomenon. They can get the value of the vehicle into the cost faster. It is therefore possible to reduce income tax by significant amounts, which is of great importance even at a time when the business environment is going through a crisis caused by a global coronavirus pandemic.

A great advantage is the possibility to depreciate electric cars in this way, which were procured even before 2019 .

Another change that affects the calculation of tax depreciation in 2020 is the change in rounding. Since 2020, the amount of annual depreciation as well as the proportional part of annual depreciation has been rounded mathematically and not as it was until 31 December 2019, to whole euros upwards.

\subsection{Changes in assets grouping}

In the next part of the paper, we will deal with changes in the classification of tangible assets into individual depreciation groups. Table 3 gives examples of classified depreciated assets during changes in legislation.

Table 3. Setting Word's margins.

\begin{tabular}{|c|c|c|c|c|c|c|}
\hline \multirow{2}{*}{$\begin{array}{l}\text { De- } \\
\text { pre- } \\
\text { cia- } \\
\text { tion }\end{array}$} & \multicolumn{6}{|c|}{ Property according depreciation groups } \\
\hline & $\begin{array}{c}\text { Act no. } \\
286 / 1992\end{array}$ & $\begin{array}{c}\text { Act no. } \\
366 / 1999\end{array}$ & $\begin{array}{c}\text { Act no. } \\
366 / 1999\end{array}$ & $\begin{array}{c}\text { Act no. } \\
595 / 2003\end{array}$ & $\begin{array}{c}\text { Act no. } \\
595 / 2003\end{array}$ & $\begin{array}{c}\text { Act no. } \\
595 / 2003\end{array}$ \\
\hline
\end{tabular}




\begin{tabular}{|c|c|c|c|c|c|c|}
\hline group & $\begin{array}{c}\text { Coll. } \\
{\text { (from } 1^{\text {st }}} \\
\text { January } \\
1993 \text { till } \\
31^{\text {st }} \\
\text { December } \\
1999 \text { ) }\end{array}$ & $\begin{array}{c}\text { Coll. } \\
{\text { (from } 1^{\text {st }}} \\
\text { January } \\
2000 \text { till } \\
31^{\text {st }} \\
\text { December } \\
2002 \text { ) }\end{array}$ & $\begin{array}{c}\text { Coll. } \\
{\text { (from } 1^{\text {st }}} \\
\text { January } \\
2003 \text { till } \\
31^{\text {st }} \\
\text { December } \\
2003 \text { ) }\end{array}$ & $\begin{array}{c}\text { Coll. } \\
{\text { (from } 1^{\text {st }}} \\
\text { January } \\
2004 \text { till } \\
31^{\text {st }} \\
\text { December } \\
2014 \text { ) }\end{array}$ & $\begin{array}{c}\text { Coll. (from } \\
1^{\text {st }} \text { January } \\
2015 \text { till } \\
31^{\text {st }} \\
\text { December } \\
2019 \text { ) }\end{array}$ & $\begin{array}{c}\text { Coll. (from } \\
1^{\text {st }} \text { January } \\
2020 \text { ) }\end{array}$ \\
\hline 0 & & & & & & electromobiles \\
\hline 1 & $\begin{array}{l}\text { Cars and } \\
\text { vans, buses, } \\
\text { computer } \\
\text { programs, } \\
\text { poultry, pigs }\end{array}$ & $\begin{array}{l}\text { Breeding } \\
\text { animals, } \\
\text { plastic } \\
\text { products, } \\
\text { office } \\
\text { machines, } \\
\text { cars, buses, } \\
\text { bicycles }\end{array}$ & $\begin{array}{l}\text { Breeding } \\
\text { animals, } \\
\text { plastic } \\
\text { products, } \\
\text { office } \\
\text { machines, } \\
\text { cars, buses, } \\
\text { bicycles }\end{array}$ & $\begin{array}{l}\text { Breeding } \\
\text { animals, } \\
\text { plastic } \\
\text { products, } \\
\text { office } \\
\text { machines, } \\
\text { cars, buses, } \\
\text { bicycles }\end{array}$ & $\begin{array}{c}\text { Animals, tools, } \\
\text { tarpaulins, } \\
\text { computers, } \\
\text { agricultural and } \\
\text { food } \\
\text { machinery, } \\
\text { cars, buses, } \\
\text { bicycles }\end{array}$ & $\begin{array}{l}\text { Animals, tools, } \\
\text { tarpaulins, } \\
\text { computers, } \\
\text { agricultural and } \\
\text { food machinery, } \\
\text { cars, buses, } \\
\text { bicycles }\end{array}$ \\
\hline 2 & $\begin{array}{c}\text { Trucks, } \\
\text { tractors, } \\
\text { aircraft, } \\
\text { inventory, } \\
\text { intangible } \\
\text { assets }\end{array}$ & $\begin{array}{l}\text { Horses, } \\
\text { textiles, } \\
\text { marine } \\
\text { engines, } \\
\text { forging } \\
\text { products, } \\
\text { pumps, } \\
\text { conveyors, } \\
\text { trolleybuses, } \\
\text { electric buses, } \\
\text { motorcycles, } \\
\text { furniture }\end{array}$ & $\begin{array}{l}\text { Horses, } \\
\text { textiles, } \\
\text { marine } \\
\text { engines, } \\
\text { forging } \\
\text { products, } \\
\text { pumps, } \\
\text { conveyors, } \\
\text { trolleybuses, } \\
\text { electric buses, } \\
\text { motorcycles, } \\
\text { furniture }\end{array}$ & $\begin{array}{c}\text { Horses, } \\
\text { textiles, } \\
\text { marine } \\
\text { engines, } \\
\text { forging } \\
\text { products, } \\
\text { pumps, } \\
\text { conveyors, } \\
\text { trolleybuses, } \\
\text { electric } \\
\text { buses, } \\
\text { motorcycles, } \\
\text { furniture }\end{array}$ & $\begin{array}{l}\text { Horses, textiles, } \\
\text { marine engines, } \\
\text { metal products, } \\
\text { pumps, } \\
\text { trolleybuses, } \\
\text { pumps, } \\
\text { trolleybuses, } \\
\text { handling } \\
\text { equipment, } \\
\text { electric buses, } \\
\text { motorcycles, } \\
\text { furniture }\end{array}$ & $\begin{array}{l}\text { Horses, textiles, } \\
\text { marine engines, } \\
\text { metal products, } \\
\text { pumps, } \\
\text { trolleybuses, } \\
\text { pumps, } \\
\text { trolleybuses, } \\
\text { handling } \\
\text { equipment, } \\
\text { electric buses, } \\
\text { motorcycles, } \\
\text { furniture }\end{array}$ \\
\hline 3 & $\begin{array}{c}\text { Portable and } \\
\text { mobile } \\
\text { machinery } \\
\text { and } \\
\text { equipment, } \\
\text { fuel furnaces, } \\
\text { larger means } \\
\text { of transport, } \\
\text { breeding and } \\
\text { draft animals }\end{array}$ & \begin{tabular}{|} 
Prefabricated \\
buildings, \\
turbines, \\
electric \\
motors, \\
generators, \\
ships, \\
locomotives, \\
growing \\
units, filing \\
cabinets
\end{tabular} & $\begin{array}{l}\text { Prefabricated } \\
\text { buildings, } \\
\text { turbines, } \\
\text { electric } \\
\text { motors, } \\
\text { generators, } \\
\text { ships, } \\
\text { locomotives, } \\
\text { growing units, } \\
\text { turbines, } \\
\text { filing cabinets }\end{array}$ & $\begin{array}{c}\text { Prefabricated } \\
\text { buildings, } \\
\text { turbines, } \\
\text { electric } \\
\text { motors, } \\
\text { generators, } \\
\text { ships, } \\
\text { locomotives, } \\
\text { growing } \\
\text { units, filing } \\
\text { cabinets }\end{array}$ & $\begin{array}{l}\text { Turbines, } \\
\text { electric motors, } \\
\text { generators, } \\
\text { furnaces, } \\
\text { marine engines, } \\
\text { cooling and } \\
\text { ventilation } \\
\text { equipment, } \\
\text { distillation } \\
\text { apparatus, } \\
\text { metallurgical } \\
\text { machines }\end{array}$ & $\begin{array}{l}\text { Turbines, electric } \\
\text { motors, } \\
\text { generators, } \\
\text { furnaces, marine } \\
\text { engines, cooling } \\
\text { and ventilation } \\
\text { equipment, } \\
\text { distillation } \\
\text { apparatus, } \\
\text { metallurgical } \\
\text { machines }\end{array}$ \\
\hline 4 & $\begin{array}{l}\text { Light con- } \\
\text { structions, } \\
\text { railway } \\
\text { super- } \\
\text { structures, } \\
\text { energy } \\
\text { driving } \\
\text { machines }\end{array}$ & $\begin{array}{c}\text { Towers, } \\
\text { chimneys, } \\
\text { railway } \\
\text { superstructure } \\
\text { s, pipes and } \\
\text { railway } \\
\text { conduits, } \\
\text { buildings and } \\
\text { structures of } \\
\text { wood }\end{array}$ & $\begin{array}{l}\text { Buildings of } \\
\text { wood and } \\
\text { plastics, } \\
\text { tanks, } \\
\text { railways and } \\
\text { tracks, pipes, } \\
\text { mining and } \\
\text { agricultural } \\
\text { buildings }\end{array}$ & $\begin{array}{l}\text { Buildings } \\
\text { and civil } \\
\text { engineering }\end{array}$ & $\begin{array}{c}\text { Prefabricated } \\
\text { buildings, } \\
\text { tanks, ships, } \\
\text { locomotives, } \\
\text { combat } \\
\text { vehicles, } \\
\text { growing units, } \\
\text { nets and lines, } \\
\text { detachable } \\
\text { components of } \\
\text { buildings (eg } \\
\text { escalators) }\end{array}$ & $\begin{array}{c}\text { Prefabricated } \\
\text { buildings, tanks, } \\
\text { ships, } \\
\text { locomotives, } \\
\text { combat vehicles, } \\
\text { growing units, } \\
\text { nets and lines, } \\
\text { detachable } \\
\text { components of } \\
\text { buildings (eg } \\
\text { escalators) }\end{array}$ \\
\hline 5 & $\begin{array}{l}\text { Buildings, } \\
\text { halls, }\end{array}$ & $\begin{array}{l}\text { Buildings, } \\
\text { halls (except }\end{array}$ & $\begin{array}{l}\text { Buildings } \\
\text { (except for }\end{array}$ & - & $\begin{array}{l}\text { Buildings } \\
\text { (excluding }\end{array}$ & $\begin{array}{l}\text { Buildings } \\
\text { (excluding }\end{array}$ \\
\hline
\end{tabular}




\begin{tabular}{|c|c|c|c|c|c|c|}
\hline structures & in group 4) & $\begin{array}{c}\text { exceptions in } \\
\text { 4), civil } \\
\text { engineering }\end{array}$ & & $\begin{array}{c}\text { exceptions in } \\
\text { group 6), civil } \\
\text { engineering }\end{array}$ & $\begin{array}{c}\text { exceptions in } \\
\text { group 6), civil } \\
\text { engineering }\end{array}$ \\
\hline 6 & & & $\begin{array}{c}\text { Residential } \\
\text { buildings, } \\
\text { hotels, office } \\
\text { buildings, } \\
\text { buildings for } \\
\text { buildings, hotels, } \\
\text { office buildings, } \\
\text { buildings for } \\
\text { healthcare and } \\
\text { healthcare and } \\
\text { education }\end{array}$ \\
\hline
\end{tabular}

Source: Cited acts.

In the table we see that some types of tangible assets were moved to lower depreciation groups, so their depreciation period was shortened.

\section{Depreciation in Czech Republic}

According to the valid Income Tax Act (Act No. 586/1992 Coll. Act of the Czech National Council on Income Taxes) depreciation is possible in the Czech Republic using similar methods as in Slovakia. Recognized methods are uniform, accelerated, or. certain modulations of these methods such as: uniform time or power. As in Slovakia, the taxpayer first classifies the acquired assets into the depreciation group according to the annex to the law. In the Czech Republic, the division of assets into 6 depreciation groups has been valid for a long time (Table 4).

Table 4. Grouping of property in Czech Republic

\begin{tabular}{|c|c|c|}
\hline $\begin{array}{l}\text { Depre- } \\
\text { ciation } \\
\text { group }\end{array}$ & $\begin{array}{c}\text { Minimum } \\
\text { depreciation } \\
\text { period (years) }\end{array}$ & Chosen items of property \\
\hline 1 & 3 & $\begin{array}{c}\text { computers, software, office equipment, animals, television } \\
\text { cameras ... }\end{array}$ \\
\hline 2 & 5 & $\begin{array}{c}\text { machinery and equipment, trucks, tractors, two-wheeled motor } \\
\text { vehicles, plastic prefabricated building parts and assemblies, } \\
\text { pumps, construction cranes, refrigeration and freezing equipment, } \\
\text { vending machines, machine tools and forming machines, } \\
\text { transmitters for radio and television broadcasting, trolleybuses, } \\
\text { aircraft ... }\end{array}$ \\
\hline 3 & 10 & $\begin{array}{c}\text { metal structures for bridges, handling equipment, ships, elevators, } \\
\text { metal products, prefabricated and building parts of concrete and } \\
\text { reinforced concrete, metal tanks, reservoirs, containers, steam } \\
\text { boilers, turbines, furnaces, burners, cranes, air conditioning } \\
\text { equipment, electric motors, generators, transformers, } \\
\text { locomotives... }\end{array}$ \\
\hline 4 & 20 & $\begin{array}{l}\text { product pipelines (gas pipelines, oil pipelines, water pipelines, } \\
\text { etc.), towers, masts, chimneys, silos, wooden and plastic } \\
\text { buildings, fencing of buildings and civil engineering works, silos, } \\
\text { local and long-distance pipe, telecommunication and electric } \\
\text { lines, towers, masts, power plant constructions, industrial } \\
\text { chimneys, swimming pools ... }\end{array}$ \\
\hline 5 & 30 & $\begin{array}{l}\text { buildings except for buildings listed in depreciation groups } 4 \text { and } \\
6, \text { motorways, roads, roads, bridges, tunnels, underpasses, } \\
\text { underpasses, ports, dams, sewage treatment plants, wells, } \\
\text { fountains, buildings for sports and recreation ... }\end{array}$ \\
\hline
\end{tabular}




\begin{tabular}{|c|c|c|}
\hline 6 & 50 & $\begin{array}{c}\text { hotel buildings, administrative, houses, for social and cultural } \\
\text { purposes, underground shopping centres, museums and libraries, } \\
\text { historical or cultural monuments ... }\end{array}$ \\
\hline
\end{tabular}

Source: Act No. 586/1992 Coll. Act of the Czech National Council on Income Taxes

As in Slovakia and the Czech Republic, it is permitted not to apply depreciation or to interrupt depreciation, but during further depreciation it is necessary to continue in such a way that depreciation is not interrupted at all. The following limits apply to the mandatory inclusion in fixed assets:

a) tangible assets with an entry price from CZK 40,000 (approx. EUR 1,480),

b) intangible assets with an entry price of 60,000 or more (approximately EUR 2,220).

The calculation of straight-line depreciation is fundamentally different from the calculation used in Slovakia. In the case of straight-line depreciation of tangible assets, the following maximum depreciation rates are assigned to the depreciation groups (Table 5):

Table 5. Depreciation rates for straight-line depreciation in Czech Republic

\begin{tabular}{|c|c|c|c|}
\hline \multirow{2}{*}{$\begin{array}{c}\text { Depreciation } \\
\text { group }\end{array}$} & \multicolumn{3}{|c|}{ Annual depreciation rate } \\
\cline { 2 - 4 } & $\begin{array}{c}\text { First year of } \\
\text { depreciation }\end{array}$ & $\begin{array}{c}\text { Following years } \\
\text { of depreciation }\end{array}$ & $\begin{array}{c}\text { For increased } \\
\text { residual value }\end{array}$ \\
\hline 1 & 20 & 40 & 33,3 \\
\hline 2 & 11 & 22,25 & 20 \\
\hline 3 & 5,5 & 10,5 & 10 \\
\hline 4 & 2,15 & 5,15 & 5,0 \\
\hline 5 & 1,4 & 3,4 & 3,4 \\
\hline 6 & 1,02 & 2,02 & 2 \\
\hline
\end{tabular}

Source: Act No. 586/1992 Coll. Act of the Czech National Council on Income Taxes

According to the valid Czech regulations, it is also possible to increase the depreciation by a certain percentage in the first year of depreciation, provided that the taxpayer is the first owner of tangible assets. This measure is of great importance in supporting the renewal of machinery by entrepreneurs, which should contribute to greener operation.

- by $20 \%$ (a taxpayer with predominantly agricultural and forestry production, which is a taxpayer whose income from this activity amounted to more than $50 \%$ of his total income in the previous tax period),

- by $15 \%$ (taxpayers operating facilities for water purification and treatment, sorting and treatment facilities for the recovery of secondary raw materials),

- by $10 \%$ (other taxpayers who are the first owners of tangible assets classified in depreciation groups 1 to 3, except aircraft, motorcycles, cars, household appliances, etc.)

In the case of accelerated depreciation, in the first year the basis for the calculation is the input price of tangible assets, in the following years its residual price (or increased residual value, if there has been a technical improvement in the meantime).

In the case of accelerated depreciation of tangible assets, the following coefficients are assigned to the depreciation groups (table 6): 
Table 6. Depreciation rates for accelerated depreciation in Czech Republic

\begin{tabular}{|c|c|c|c|}
\hline \multirow{2}{*}{$\begin{array}{c}\text { Depreciation } \\
\text { group }\end{array}$} & \multicolumn{3}{|c|}{ Annual depreciation rate } \\
\cline { 2 - 4 } & $\begin{array}{c}\text { First year of } \\
\text { depreciation }\end{array}$ & $\begin{array}{c}\text { Following years } \\
\text { of depreciation }\end{array}$ & $\begin{array}{c}\text { For increased } \\
\text { residual value }\end{array}$ \\
\hline 1 & 3 & 4 & 3 \\
\hline 2 & 5 & 6 & 5 \\
\hline 3 & 10 & 11 & 10 \\
\hline 4 & 20 & 21 & 20 \\
\hline 5 & 30 & 31 & 30 \\
\hline 6 & 50 & 51 & 50 \\
\hline
\end{tabular}

Source: Act No. 586/1992 Coll. Act of the Czech National Council on Income Taxes

In the case of accelerated depreciation, depreciation of tangible assets in the 1st year of depreciation $\left(\mathrm{D}_{1}\right)$ is calculated:

$$
D_{1}=\text { entry price of property / coefficient in first year of depreciation }
$$

In following years of depreciation, depreciation of tangible assets (D) is calculated:

$D=2 x$ residual price of property / (coefficient in following years of depreciation - number of years when the property just was depreciated)

The possibility of applying increased depreciation in the first year of depreciation also applies.

\subsection{Comparison of depreciation systems of Slovak and Czech Republic}

Let us give an example of calculating a depreciation plan for fixed assets in Slovakia and the Czech Republic. Let us imagine that this is an asset - a car with a purchase price of 12,000 EUR. A technical evaluation of EUR 6000 will be carried out in September 2020. The car is included in the first depreciation group in Slovakia and in the second depreciation group in the Czech Republic.

Calculation of depreciation in Slovak Republic.

\begin{tabular}{|c|c|c|c|c|c|}
\hline Year & Depreciation calculation & $\begin{array}{c}\text { Total year } \\
\text { depreciation }\end{array}$ & $\begin{array}{c}\text { Applied in } \\
\text { the year }\end{array}$ & $\begin{array}{c}\text { Non-applied } \\
\text { depreciation }\end{array}$ & $\begin{array}{c}\text { Residual } \\
\text { value }\end{array}$ \\
\hline 2020 & {$[(12000+6000 / 4) / 12] \times 9$} & 4500 & 3375 & 1125 & 14625 \\
\hline 2021 & $18000 / 4$ & 4500 & 4500 & & 10125 \\
\hline 2022 & $18000 / 4$ & 4500 & 4500 & & 5625 \\
\hline 2023 & $18000 / 4$ & 4500 & 4500 & & 1125 \\
\hline 2024 & & & 1125 & & 0 \\
\hline
\end{tabular}




\begin{tabular}{|l|l|l|l|l|l|}
\hline Total & & & 18000 & & \\
\hline
\end{tabular}

Depreciation calculation in the Czech Republic - we will not use the conversion to the Czech currency to illustrate the example.

\begin{tabular}{|c|c|c|c|c|c|}
\hline Year & Depreciation calculation & $\begin{array}{c}\text { Total year } \\
\text { depreciation }\end{array}$ & $\begin{array}{c}\text { Applied in } \\
\text { the year }\end{array}$ & $\begin{array}{c}\text { Non-applied } \\
\text { depreciation }\end{array}$ & $\begin{array}{c}\text { Residual } \\
\text { value }\end{array}$ \\
\hline 2020 & $(18000 \times 11) / 100$ & 1980 & 1980 & & 16020 \\
\hline 2021 & $(18000 \times 22,25) / 100$ & 4005 & 4005 & & 12015 \\
\hline 2022 & $(18000 \times 22,25) / 100$ & 4005 & 4005 & & 8010 \\
\hline 2023 & $(18000 \times 22,25) / 100$ & 4005 & 4005 & & 4005 \\
\hline 2024 & $(18000 \times 22,25) / 100$ & 4005 & 4005 & & 0 \\
\hline Total & & & 18000 & & \\
\hline
\end{tabular}

From the comparison of equal depreciation, we see that the Slovak system provides the possibility of faster inclusion of the input price of assets in the company's costs even if the condition of conversion to the real number of months of use in the first year is met. The accelerated depreciation method cannot be applied to this specific example, as accelerated depreciation in the conditions of the Slovak Republic can be used only for tangible assets included in depreciation groups 2 and 3.

To compare accelerated depreciation, we will therefore choose a new example - a pump, where assets in both cases are included in the second depreciation group at a cost of EUR 24,000 in July 2020.

Calculation of depreciation in Slovak Republic.

\begin{tabular}{|c|c|c|c|c|c|}
\hline Year & $\begin{array}{c}\text { Depreciation } \\
\text { calculation }\end{array}$ & $\begin{array}{c}\text { Total year } \\
\text { depreciation }\end{array}$ & $\begin{array}{c}\text { Applied in } \\
\text { the year }\end{array}$ & $\begin{array}{c}\text { Non-applied } \\
\text { depreciation }\end{array}$ & Residual value \\
\hline 2020 & {$[(24000 / 6) / 12] \times 6$} & 4000 & 2000 & 2000 & $20000(+2000)$ \\
\hline 2021 & $(2 \times 20000) / 7-1$ & 6667 & 6667 & & $13333(+2000)$ \\
\hline 2022 & $(2 \times 20000) / 7-2$ & 5334 & 5334 & & $7999(+2000)$ \\
\hline 2023 & $(2 \times 20000) / 7-3$ & 4000 & 4000 & & $3999(+2000)$ \\
\hline 2024 & $(2 \times 20000) / 7-4$ & 2667 & 2667 & & $1332(+2000)$ \\
\hline 2025 & $(2 \times 20000) / 7-5$ & 1332 & 1332 & & $0(+2000)$ \\
\hline 2026 & & & 2000 & & 0 \\
\hline Total & & & 24000 & & \\
\hline
\end{tabular}

Depreciation calculation in the Czech Republic 


\begin{tabular}{|c|c|c|c|c|c|}
\hline Year & $\begin{array}{c}\text { Depreciation } \\
\text { calculation }\end{array}$ & $\begin{array}{c}\text { Total year } \\
\text { depreciation }\end{array}$ & $\begin{array}{c}\text { Applied in } \\
\text { the year }\end{array}$ & $\begin{array}{c}\text { Non-applied } \\
\text { depreciation }\end{array}$ & Residual value \\
\hline 2020 & $24000 / 5$ & 4800 & 4800 & & 19200 \\
\hline 2021 & $(19200 \times 2) /(6-1)$ & 7680 & 7680 & & 11520 \\
\hline 2022 & $(11520 \times 2) /(6-2)$ & 5760 & 5760 & & 5760 \\
\hline 2023 & $(5760 \times 2) /(6-3)$ & 3840 & 3840 & & 1920 \\
\hline 2024 & $(1920 \times 2) /(6-4)$ & 1920 & 1920 & & 0 \\
\hline Total & & & 24000 & & \\
\hline
\end{tabular}

From a business point of view, the Czech calculation system is therefore more advantageous, as it offers a faster transfer of the input price of assets to the company's costs than the system used in Slovakia. It is also disadvantageous for our entrepreneurs that the accelerated depreciation method is applicable only to selected types of assets.

The given examples are illustrative, in order to draw a general conclusion, it would be necessary to recalculate several types of assets.

\section{Conclusions and discussion}

Depreciation of assets in the conditions of the Slovak Republic has undergone many years of development. At the beginning he was influenced by the joint management of Slovakia and the Czech Republic, gradually both countries found their own way. While the Czech Republic is building on the foundations of the original common law on income tax, the Slovak Republic has adopted its own laws.

In the presented paper, we analysed the development in depreciation of fixed assets in Slovakia and the Czech Republic. Based on the above findings, we can conclude the following:

- Income tax and depreciation as such are subject to frequent changes. In Slovakia, these changes mainly concerned the regrouping of types of assets into different depreciation groups, so the depreciation policy in Slovakia is relatively unstable.

- The changes that have been made in the area of depreciation have been favourable in the business environment.

- The limits on the input prices of assets, from which assets are compulsorily included in depreciation, have gradually increased. This is a positive phenomenon, which allowed entrepreneurs to immediately include lower-priced assets in costs and ultimately reduce the resulting income tax.

- Several ecological steps have been taken to adjust the depreciation. These include the reduction of the depreciation period for buildings, large vehicles and the last measure the creation of a special depreciation group for electric cars.

- The preferential method of depreciation of electric vehicles can also be applied to those electric vehicles that were put into use as of 31 December 2018. Tax depreciation that has already been applied is not corrected.

- When comparing the depreciation system in Slovakia and the Czech Republic, we can state that the Slovak method of calculation is simpler. The depreciation system in the Slovak Republic, using the straight-line method, enables faster depreciation of assets 
compared to the depreciation system in the Czech Republic. However, this does not apply in general, as the division of assets in depreciation groups is not harmonized.

- As accelerated depreciation is permitted in the Slovak Republic only for assets classified in depreciation groups 2 and 3, the accelerated depreciation system is more advantageous in the Czech Republic. At this point, it is necessary to emphasize the clear advantage for entrepreneurs in the Czech Republic, which is allowed to increase depreciation in the first year of use of assets by a certain percentage and thus get a larger item in costs at a time when the property does not yet incur repairs or maintenance costs.

To move closer to international standards, the Slovak Republic has made significant changes in its depreciation over the course of its history. It is worth noting that these changes have been beneficial for the business environment. In the future, however, it is appropriate to consider another alternative to the calculation of depreciation, where the entrepreneur could adjust the depreciation himself, not on the basis of an official calculation, but on the basis of a predetermined plan reflecting the plan of use of the asset.

The paper was processed within the solution and with the support of the project VEGA 1/0121/20: Research of transfer pricing system as a tool to measure the performance of national and multinational companies in the context of earnings management in conditions of the Slovak Republic and V4 countries.

\section{References}

1. Mintal, J. (2019). Optimalizacia zakladu dane - prerueenie odpisovania. Dane, uctovnictvo, odvody, 2/2020, $16-19$.

2. Mintal, J. (2019). Odpisovanie majetku - priklady z praxe. Dane, uctovnictvo, odvody, $7-8 / 2020,82-83$.

3. Kolembus, A. (2019). Odpisovanie dlhodobeho majetku. Dane, uctovnictvo, odvody, 45/2020, 30-31.

4. Bielena, J. (2019). Danove odpisy a danova optimalizacia. Dane, uctovnictvo, odvody, 1/2020, 39-41.

5. Durinova, I. (2012). Vyvoj odpisovej politiky v kontexte zdanovania prijmov v SR. Biatec, 2/2012, 20-23.

6. Eckert, A., Mecca, M. S., Biasio, R., de Oliveira, P. D. (2012). Changes in fixed assets arising from the convergence to international accounting standards: The case of company Alfa. Revista Ambiente Contabil, 4(2), 56-73.

7. Pernica, M., Hanusova, H. (2015). Certain Aspects of the Use of Accounting Principles in the Accounting of Public Corporations. Proceedings from the 20th International Scientific conference - Economics and Management 2015 (ICEM - 2015) (pp. 345350). Kaunas, Lithuania : Elsevier Science.

8. Tusan, R., Banociova, A., \& Buleca, J. (2013). Comparison of IFRS and Slovak Accounting Regulations in the Area of Accounting and Recognition of Noncurrent Assets. Confronting Contemporary Business Challenges through Management Innovation, 2376-2391.

9. Nechaev, AS., Ilina, EA. (2019). Integrated depreciation management system. Proceedings of the Conference on Social and Cultural Transformations in the Context of Modern Globalism (SCTCGM) (pp. 728-734). Groznyi, Russia : KarimSultanovich, BD. 
10. Johnson, N. B. (2010). Residual income compensation plans and deferred taxes. Journal of management accounting research, 22(1), 103-114.

11. Rodi, W. N. W., Ani, A. I. C., Tawil, N. M., Ting, K. H., Mahamood, N. M. (2017). A preliminary study on the relevancy of sustainable building design to commercial property depreciation. Journal of Fundamental and Applied Sciences. 9(6 - SI), 162183.

12. Elakova, A. A., Gudzhatullaeva, E. M. (2017). Assessment of trends in the reform of accounting of fixed assets in Russia. Revista publicando, 4(13), 525-533.

13. Liapis, K. J., Kantianis, D. D. (2015). Depreciation Methods and Life-Cycle Costing (LCC) Methodology. Proceedings from the $6^{\text {th }}$ International Conference on Economies of Balkan and Eastern Europe Countries in the Changed World (EBEEC 2014) (pp. 314-324). Nis, Serbia: Elsevier Science.

14. Diewert, W. E. (2016). Sunk costs and the measurement of commercial property depreciation. Canadian Journal of Economics - Revue Canadienne d Economique, 49(4), 1340-1366.

15. Rodi, W. N. W., Hwa, T. K., Mahamood, N. M., Said, A. S., Abdullah, M. I. (2015). Depreciation between Conventional and Green Office Buildings. Proceedings from the International Accounting and Business Conference 2015 (IABC 2015) (pp. 661-670). Putrajaya, Malaysia: Sanusi, Z. M. 